\title{
Game petualangan untuk meningkatkan minat belajar siswa tentang sejarah ke- merdekaan Bangsa Indonesia
}

\author{
Mochammad Alvin Tri Bachtiar ${ }^{1)}$ dan Lukman Hakim ${ }^{2)}$ \\ ${ }^{1,2)}$ Program Studi Teknik Informatika Universitas Yudharta Pasuruan \\ Jl. Yudharta 07 Sengonagung Purwosari Pasuruan \\ e-mail: phienal181@gmail.com ${ }^{1)}$, lukman@yudharta.ac.id ${ }^{2)}$
}

Info Artikel

Diserahkan 30 Oktober 2016, direvisi 23 Desember 2017, diterima 23 Desember 2017, tersedia online 23 Desember 2017

\begin{abstract}
ABSTRAK
Saat ini sistem pembelajaran sejarah sangat tidak menarik dan cenderung membosankan, salah satu solusinya adalah dengan mengemas proses belajar sejarah ke dalam bentuk game. Hasil dari penelitian ini adalah sebuah game edukasi berbasi game petualangan yang sudah diujicoba oleh guru maupun siswa di kelas VIII MTS Al-Anwar Wonorejo Kabupaten Pasuruan. Hasil penilaian terhadap game dolanan sejarah memberikan hasil yang baik (skala maksimum 4) dari aspek ketertarikan dengan skor 3,19; aspek kemanfaatan dengan skor 3,46; aspek kesesuaian kurikulum memiliki skor sebesar 3,46; dan aspek kemudahan dengan skor 3,18.
\end{abstract}

Kata kunci: game adventure, game edukasi, sejarah kemerdekaan bangsa Indonesia.

\section{ABSTRACT}

Currently, the process of learning history is less attractive; the problem is that students are less interested and bored. One solution is to package these lessons in an educational game. The game then tested by the teachers and students in class VIII MTS AL-ANWAR. The results of the assessment of the game "dolanan" history gave positive results. With a maximum scale of 4 on each aspect, we receive the following results: the aspect of interest scored 3.19, the aspect of expediency scored 3.46, curriculum suitability aspect scored 3.46, and the aspects of ease scored 3.18.

Keywords: Adventure game, education game, history of Indonesian independence.

\section{Pendahuluan}

$\mathrm{D}$ ALAM kehidupan berbangsa dan bernegara, setiap orang perlu memahami sejarah bangsanya sebagai landasan sikap untuk menghadapi tantangan ke depan. Untuk itu pemahaman tentang sejarah harus ditanamkan mulai dini melalui pendidikan formal, terutama tentang sejarah kemerdekaan bangsa Indonesia.

Sejarah memiliki peran yang sangat penting dalam membentuk karakter bangsa dan menanamkan sikap cinta tanah air [2]. Namun pembelajaran sejarah saat ini menghadapi banyak persoalan. Berdasarkan pengamatan yang dilakukan di MTS. Al-Anwar Wonorejo Kabupaten Pasuruan Provinsi Jawa Timur, proses belajar mengajar sejarah cenderung membosankan, karena metode mengajar guru masih menggunakan paradigma konvensional yaitu "guru menjelaskan-siswa mendengarkan" [1]. Metode pembelajaran seperti ini akan berakibat siswa malas dalam belajar sejarah dan melupakan sejarah bangsa sendiri [1].

Berdasarkan permasalahan tersebut, metode belajar yang bisa memberikan nuansa yang menarik menjadi faktor yang sangat penting, salah satunya menggunakan pendekatan permainan atau game yang interaktif. Game sangat efektif jika digunakan dalam pengajaran, terutama untuk penguasaan level-level sulit [3]. Selain itu pemakaian game untuk sarana pembelajaran membuat siswa lebih tertarik dan termotivasi untuk berinteraksi dengan topik yang diberikan [4].

Game sendiri memiliki banyak jenis, diantaranya Aksi, Petualangan, Edukasi, Balap, Role Playing, Simulasi, Olahraga dan Strategi [5]. Dengan banyaknya jenis game, tentu saja diperlukan pemilihan jenis game yang sesuai dengan topik yang akan diselesaikan. Dalam penelitian ini diusulkan jenis game petualangan (Adventure) agar siswa bisa lebih merasakan suasana dalam lingkungan game sejarah ini.

Game adventure merupakan program software yang mempresentasikan lingkungan tiruan dimana pemain akan berinteraksi dengan game untuk menyelesaikan tantangan yang ada dalam permainan tersebut [6].

Dengan pendekatan game adventure, siswa menjadi lebih tertarik dalam belajar sejarah terutama sejarah kemerdekaan bangsa Indonesia.

\section{Metode Penelitian}

Pendekatan pada penelitian ini menggunakan metode penelitian pengembangan (Research and Development) seperti pada Gambar 1. 


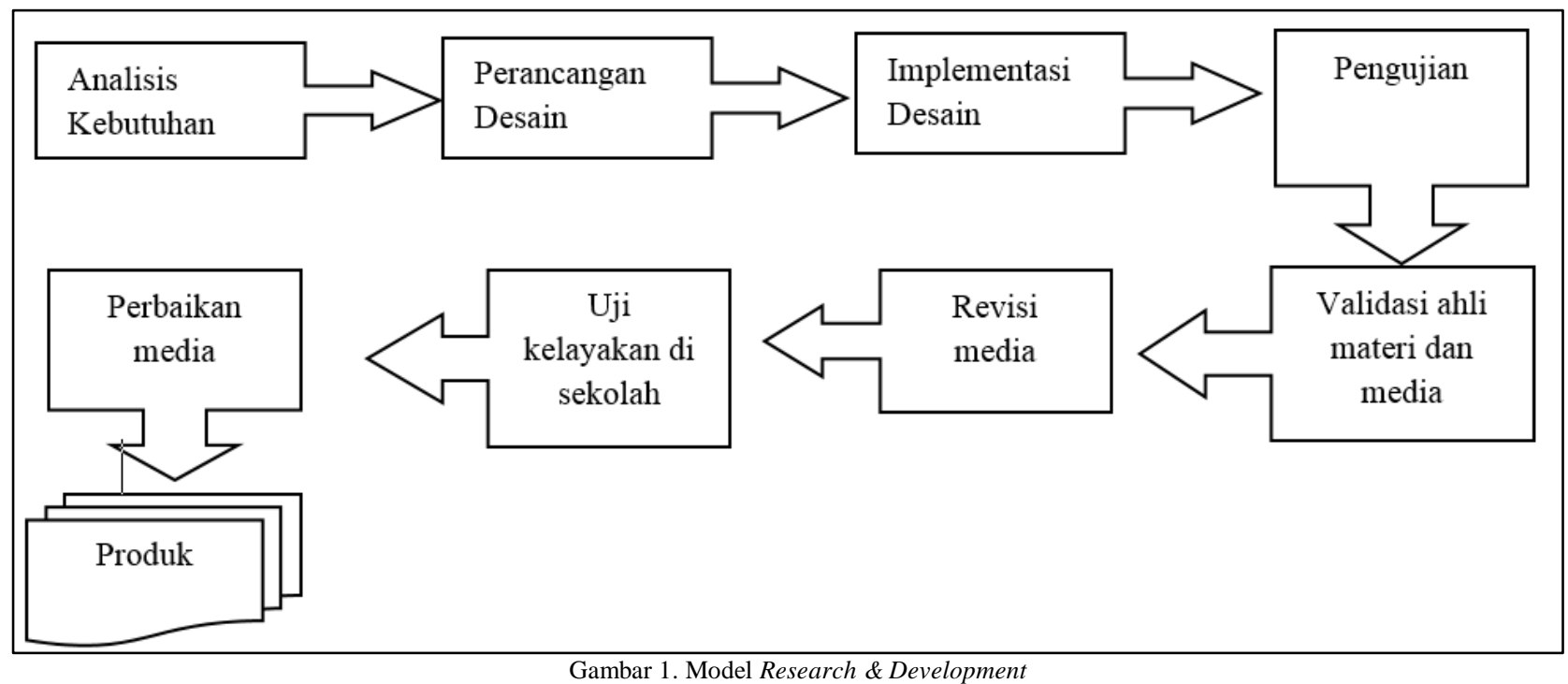

Gambar 1. Model Research \& Development

Adapun tahapan pada Gambar 1 adalah sebagai berikut:

a. Analisis Kebutuhan

Tahap analisis ini menghasilkan dua poin penting, yaitu antarmuka dan fasilitas yang ada dalam game. Interface game menggunakan warna yang cenderung glamour dan energik sehingga terlihat lebih menarik dan tidak membosankan. Untuk fitur-fitur pada game yang dibuat meliputi button mulai, keluar, berhenti, lanjut, petunjuk memainkan game, pengaturan, рор-ир yang berisi materi tentang sejarah kemerdekaan Indonesia, karekter anak kecil dan boneka, latar tempat yang menggambarkan kondisi halaman rumah, pop-up untuk menjawab soal, dan score.

b. Perancangan Desain

Pada bagian ini dilakukan perancangan game menggunakan case diagram, class diagram, dan activity diagram.

c. Implementasi Desain

Pada bagian ini dilakukan proses penerjemahan perancangan desain ke dalam tampilan yang sebenarnya. Pengembangan yang digunakan adalah game berbasis PC, program yang digunakan untuk menterjemahkan desain ini berupa program Unity dan Blender.

d. Pengujian

Pada tahapan ini game yang sudah dibuat akan diuji. Pengujian ini menggunakan blackbox. Proses pengujian dilakukan untuk mengecek tombol navigasi apakah ada kesalahan pemberian perintah, navigasi tidak bisa diakses, pengecekan interface, kesalahan pada materi, maupun kesalahan penulisan. Setelah itu akan diperiksa kembali oleh ahli media dan ahli materi.

e. Validasi ahli materi dan media

Proses ini akan memastikan di mana materi dalam game memang sudah mengikuti kurikulum yang berlaku di sekolah.

f. Revisi Media

Setelah dilakukan uji coba di lapangan, akan dilakukan perbaikan.

g. Uji kelayakan di sekolah

Pada bagian ini akan dilakukan pengujian tingkat efektivitas dari game. Uji ini dilakukan dengan menggunakan kuesioner, yang kemudian hasilnya dianalisa.

h. Perbaikan media

Pada bagian ini dilakukan perbaikan-perbaikan pada game setelah melalui proses revisi media dan uji kelayakan.

i. Produk

Setelah melewati tahap-tahap sebelumnya, dihasilkan sebuah produk media pembelajaran berupa game.

\section{HASIL DAN PEMbahaSAN}

\section{A. Pengumpulan Materi}

Pengumpulan materi dilakukan untuk mengisi materi yang akan disajikan pada game mengenai sejarah kemerdekaan Indonesia. Materi yang disajikan meliputi materi tentang pembentukan BPUPKI (Badan 
Penyelidikan Usaha-Usaha Persiapan Kemerdekaan Indonesia) dan tugas BPUPKI, pembentukan PPKI (Panitia Persiapan Kemerdekaan Indonesia) dan tugas PPKI, peristiwa Rengasdengklok, penyusunan teks proklamasi, dan pelaksanaan proklamasi.

\section{B. Mekanika Game}

Flowchart dari mekanika game disajikan dalam Gambar 2. Ketika game dimulai langsung muncul petunjuk untuk mencari sebuah objek. Jika objek ditemukan otomatis dan menampilkan pop-up pertanyaan, jika jawaban benar maka time pemain menjadi penuh kembali dan mendapatkan petunjuk selanjutnya. Jika jawaban salah time berkurang dan tidak mendapatkan petunjuk selanjutnya. Begitu seterusnya sampai menemukan petunjuk terakhir dan menang.
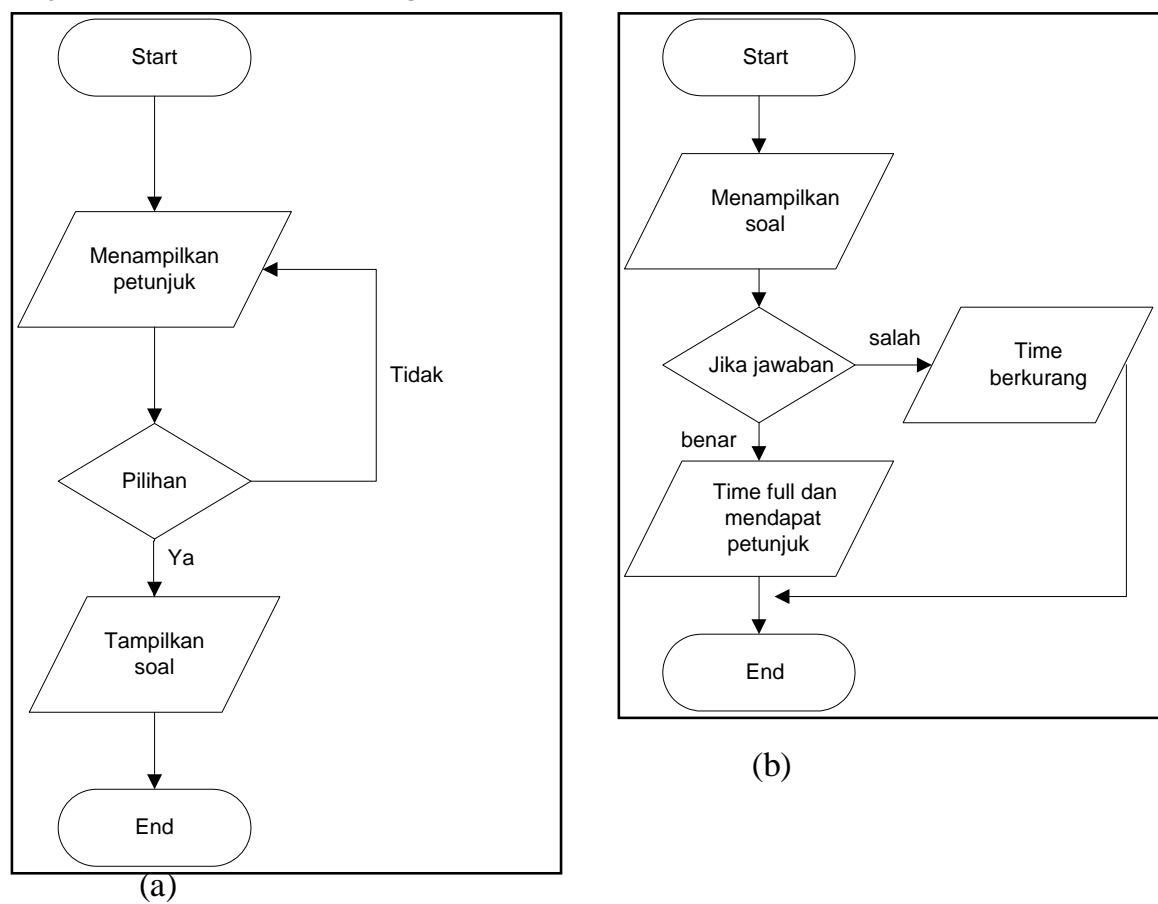

(b)

Gambar 2. Mekanika Game: (a) Flowchart untuk mencari sebuah objek. Jika objek ditemukan otomatis dan menampilkan popup pertanyaan (b) jika jawaban benar maka time pemain menjadi penuh kembali dan mendapatkan petunjuk selanjutnya

\section{Storyboard}

Perancangan storyboard ini berisi alur cerita dari game yang akan ditampilkan dalam bentuk tulisan dan gambar. Storyboard ini dibagi dalam 6 frame yaitu tampilan menu game, materi, tampilan awal, proses pencarian objek, menemukan objek, dan dan tampilan menang. Gambar 3 merupakan gambaran dari tampilan menu pembuka, di mana merupakan halaman yang pertama kali muncul saat aplikasi dijalankan.

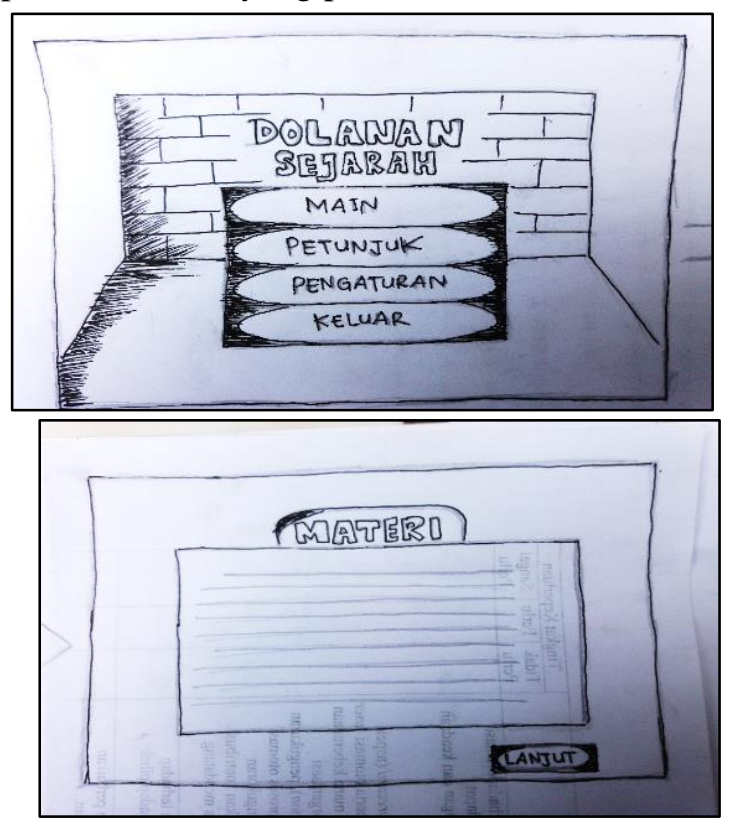

Gambar 3. Frame menu utama

Gambar 4. Frame tampilan materi 


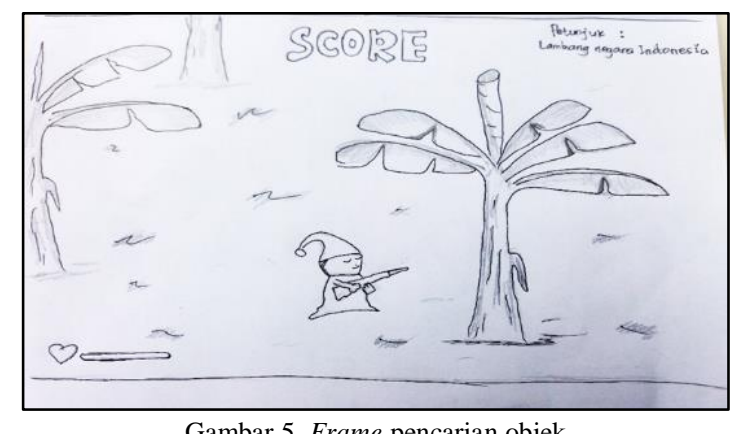

Gambar 5. Frame pencarian objek

Gambar 4 menjelaskan mengenai tampilan materi, yang mana merupakan halaman setelah tombol main di klik. Sebelum memainkan game ada beberapa materi yang harus dikuasai agar bisa menjawab soal yang disajikan pada permainan. Setelah mempelajari materi yang disajikan sebelumnya, maka pengguna dapat langsung memulai permainan, di mana aktor harus menyelesaikan misi yang sudah diberikan. Petunjuk untuk menyelesaikan misi berada di kanan atas, yang merupakan teka-teki untuk menemukan sebuah objek (perhatikan Gambar 5 dan Gambar 6). Adapun petunjuk-petunjuk yang diberikan yaitu:

1. Senjata tradisional untuk melawan penjajah

2. Lambang negara Indonesia

3. Alat musik tradisional

4. Senjata pangeran Diponegoro

5. Merdeka

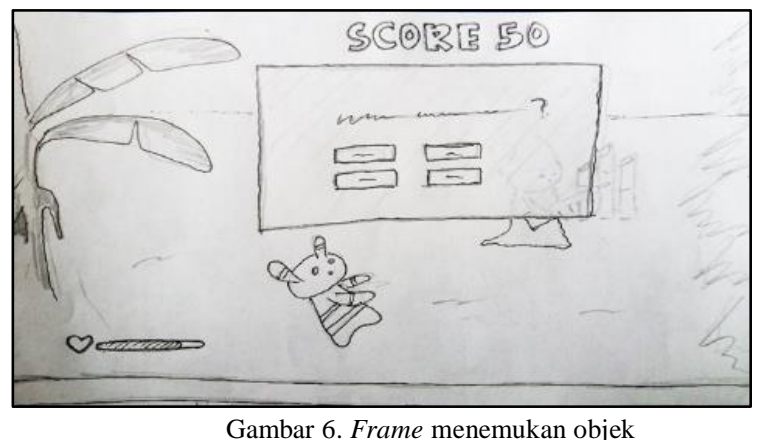

Di dalam menyelesaikan misi mencari objek yang telah diberi petunjuk, ada rintangan yang wajib dilalui oleh aktor, yaitu beberapa musuh yang mengikuti aktor. Aktor dibekali senjata untuk bisa menembak musuh. Musuh dalam game ini ada 3 jenis yaitu Zombunny, Zombear dan Elephant. Di mana musuh tersebut terus bertambah dengan waktu yang berbeda. Untuk Zombunny terus muncul 5 detik sekali dan mati jika terkena 3 kali tembakan oleh aktor dengan mendapatkan score 10, Zombear muncul 7 detik sekali dan mati jika terkena 5 kali tembakan oleh aktor dengan mendapat score 10 dan untuk Elephant muncul 20 detik sekali dan mati jika terkena 10 kali tembakan oleh aktor dengan mendapat score 50. Aktor memiliki timer 100 yaitu ketika musuh mengenai aktor maka timer dikurangi 10. Jika timer aktor sudah habis maka dinyatakan kalah.

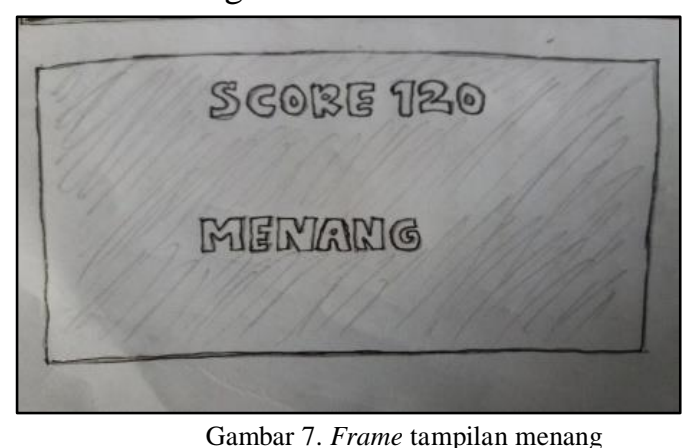

Memecahkan petunjuk yang sudah diberikan dan juga berhasil melewati musuh-musuh yang terus mendekati aktor maka proses pencarian objek terus dilakukan. Jika objek yang dicari sudah ditemukan maka aktor harus mendekati objek tersebut sampai muncul pop up pertanyaan. Soal yang disajikan adalah pilihan ganda, dimana jika menjawab dengan benar maka timer aktor menjadi penuh dan mendapatkan petunjuk baru. Jika menjawab salah maka timer aktor berkurang 20 dan tidak mendapatkan petunjuk selanjutnya. Frame yang terakhir adalah frame tampilan menang seperti pada Gambar 7. Pada frame ini, jika semua petunjuk sudah diselesaikan maka game akan menampilkan tampilan menang dan permainan selesai. 


\section{Implementasi Antarmuka}

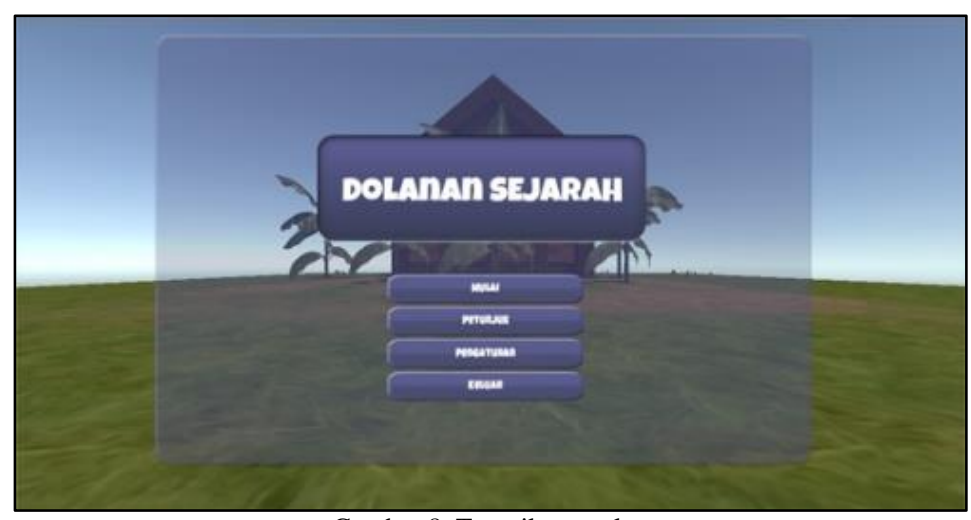

Gambar 8. Tampilan awal game

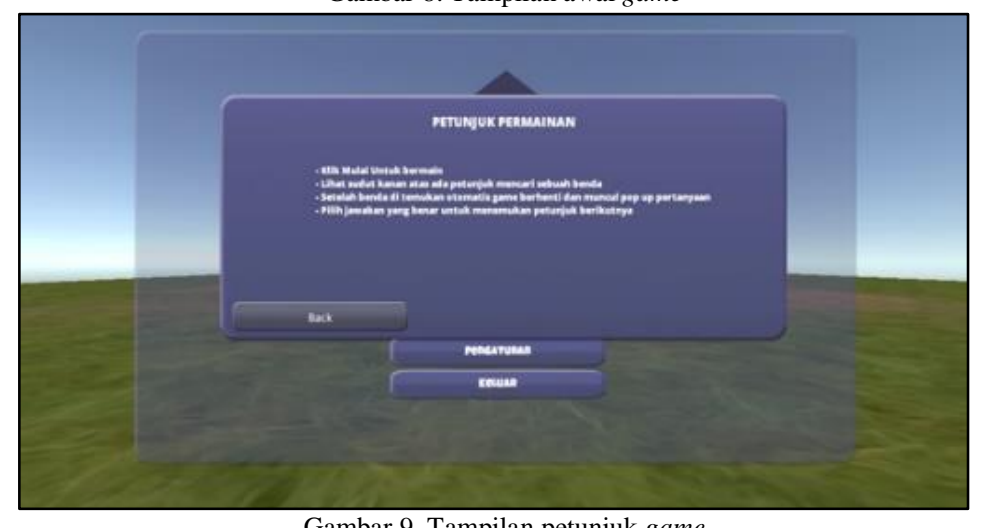

Gambar 9. Tampilan petunjuk game

Pada tampilan menu Awal terdapat 4 menu utama seperti pada Gambar 8. Menu yang ditampilkan yaitu: Mulai permainan, Petunjuk, Pengaturan, dan Keluar. Pengguna dapat memilih menu dengan cara memilih tombol menu sesuai dengan pilihan yang dikehendaki. Setelah memilih menu yang dikehendaki maka akan secara otomatis beralih ke tampilan menu yang dipilih. Tampilan pengaturan, merukan tampilan yang berisi pengaturan memainkan game. Jika pengguna memilih menu "Petunjuk", secara otomatis muncul pop-up tentang petunjuk permainan seperti yang ditampilkan pada Gambar 9.

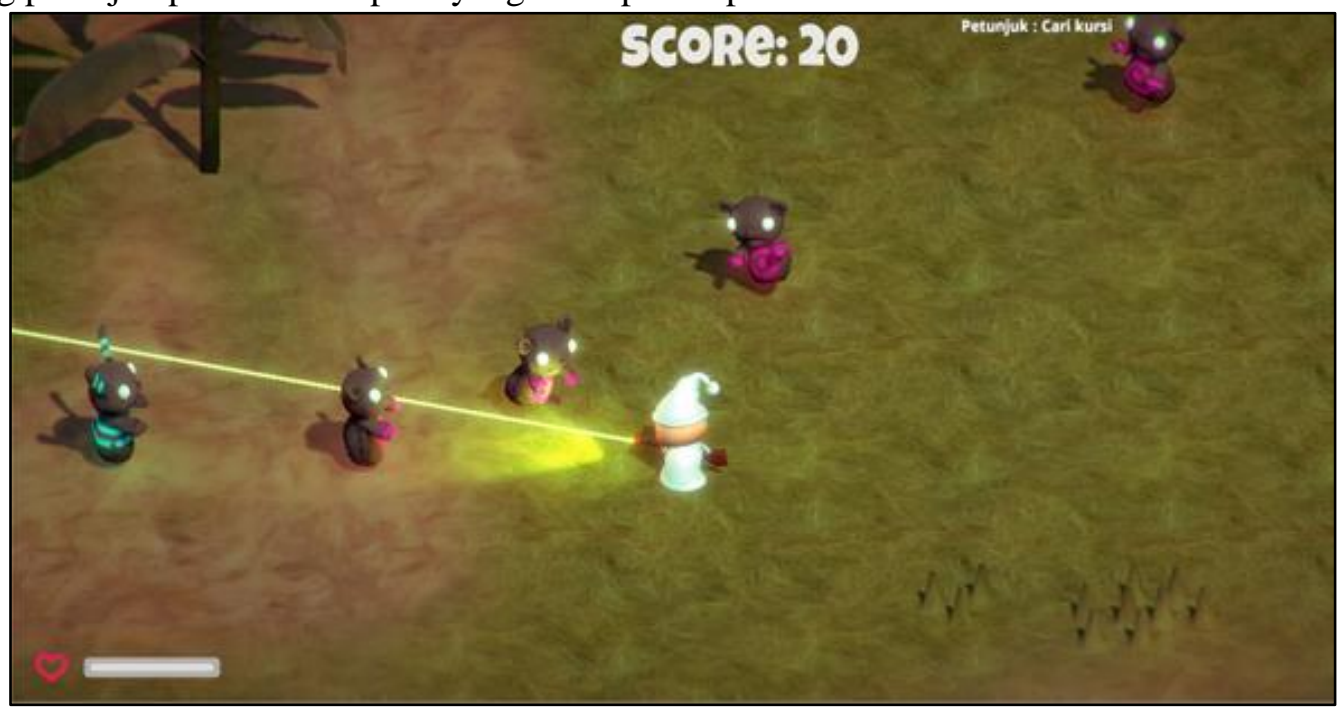

Gambar 10. Tampilan proses pencarian objek

\section{E. Tampilan Proses Pencarian Objek}

Dalam proses pencarian sebuah objek, ada beberapa rintangan yang harus dilalui. Aktor dibekali senjata untuk melewati rintangan sampai menemukan objek yang dicari, seperti pada Gambar 10. Setelah menemukan objek yang dicari (perhatikan Gambar 11), pengguna harus menyentuh objek dan secara otomatis muncul sebuah pop-up pertanyaan yang berisi soal pilihan ganda yang mengangkat materi seputar sejarah kemerdekaan bangsa Indonesia. 


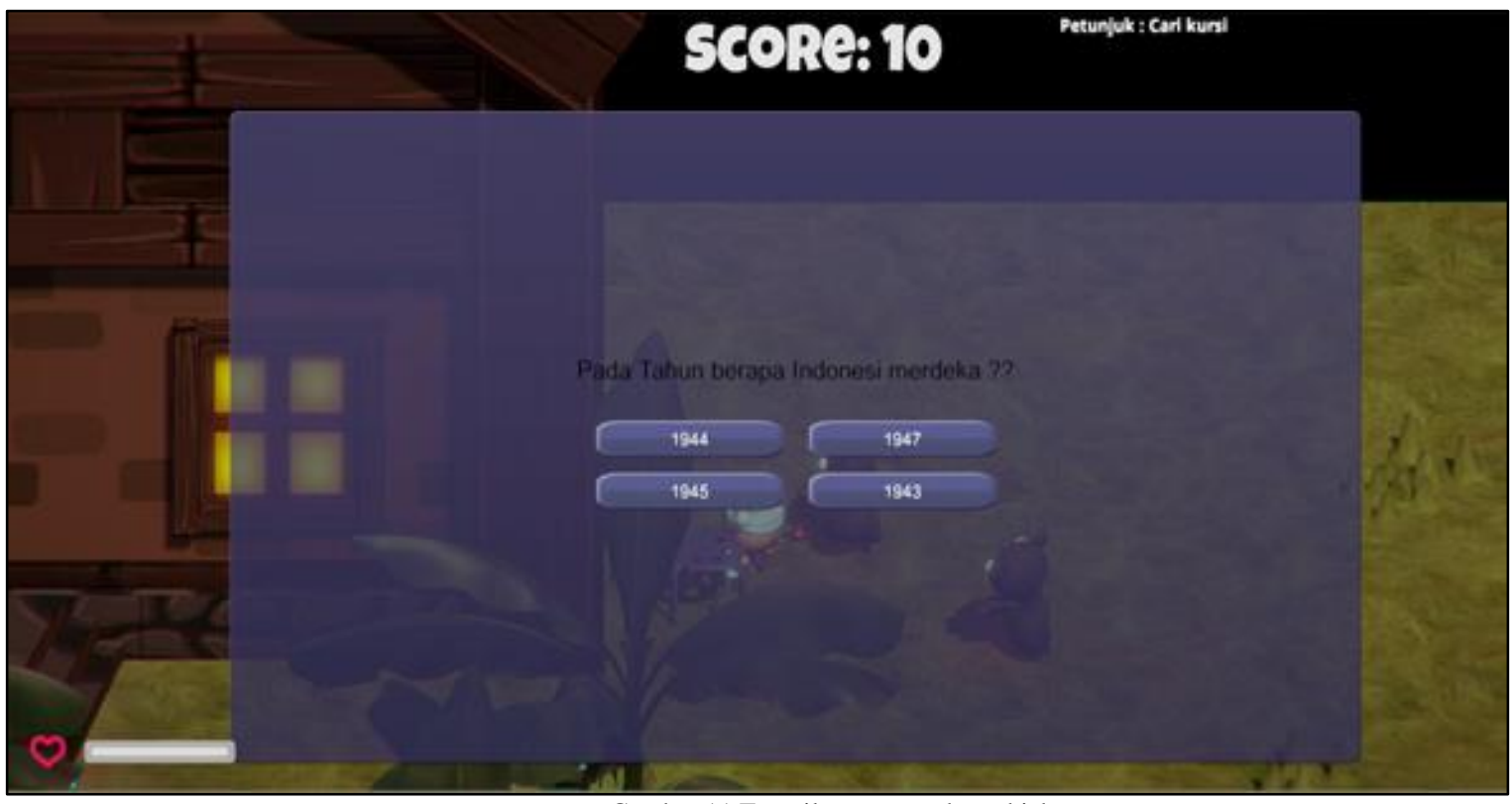

Gambar 11.Tampilan menemukan objek

\section{F. Tampilan Jawaban Benar dan Salah}

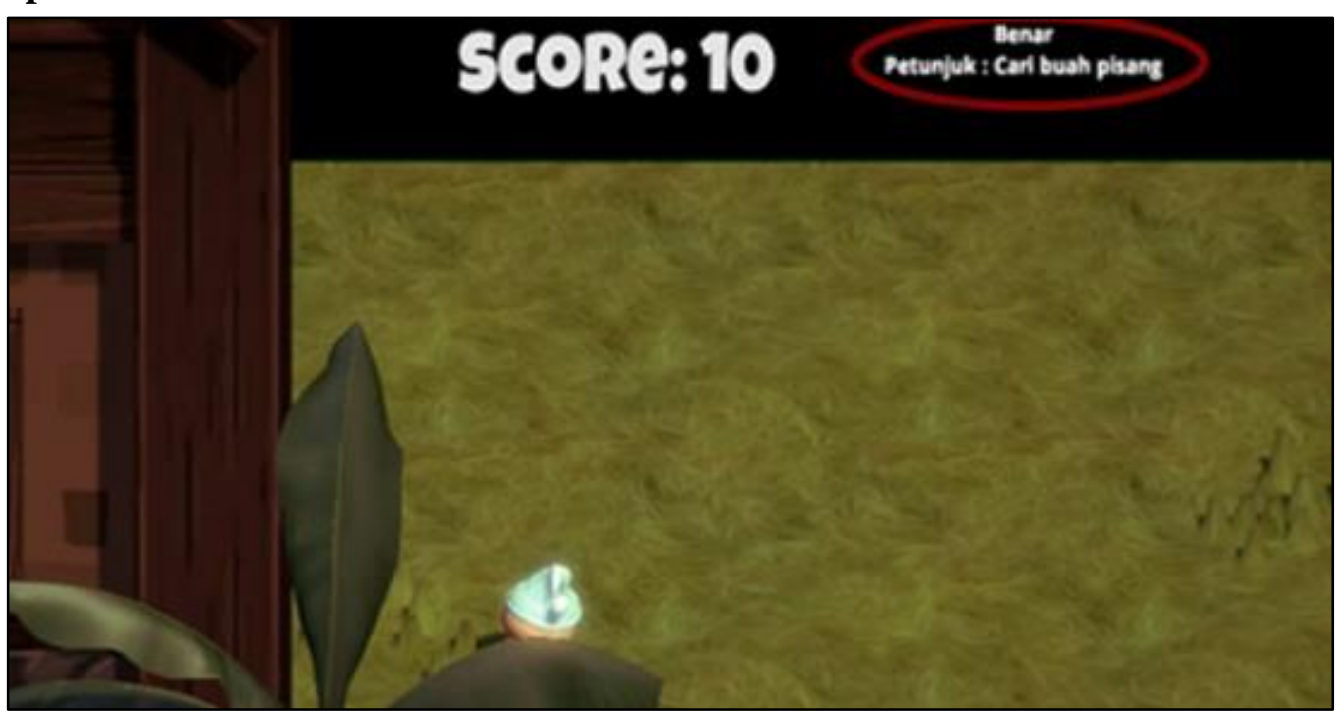

Gambar 12. Tampilan Jawaban benar

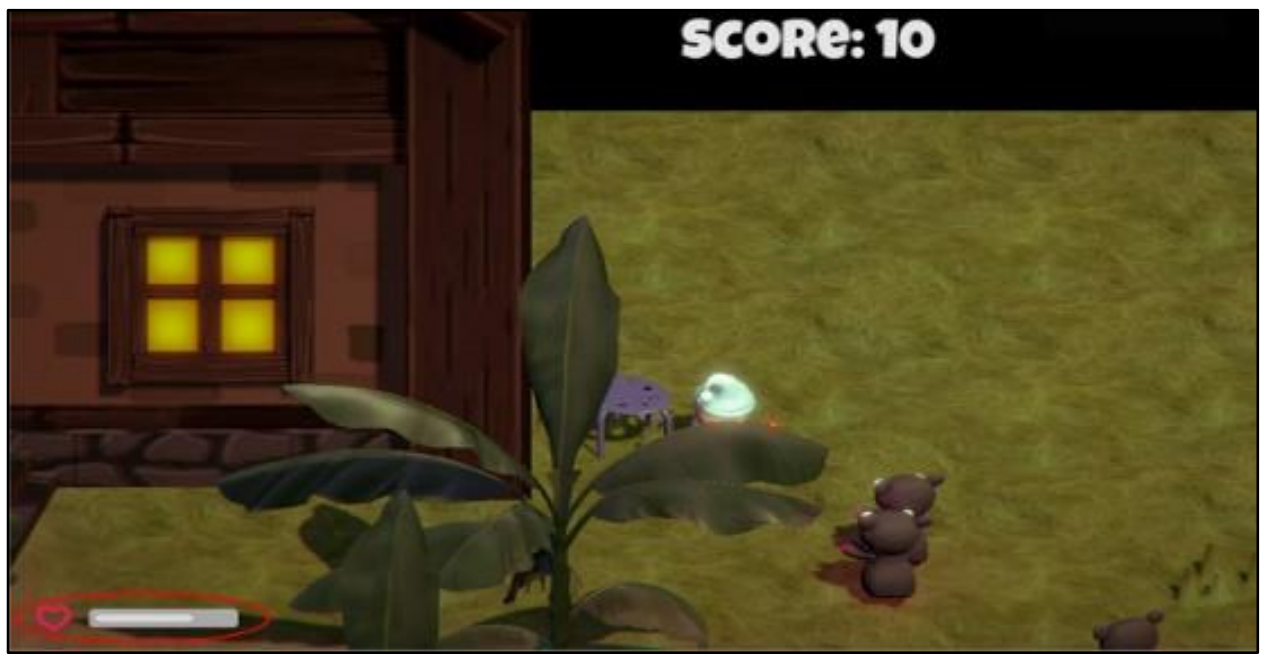

Gambar 13. Tampilan Jawaban salah

Tampilan jawaban benar akan menampilkan petunjuk baru setelah soal berhasil dijawab dan bernilai benar. Selain menampilkan petunjuk baru, tampilan jawaban benar akan menampilkan timer game yang berupa lambang hati dan darah yang akan bertambah, sebagaimana dapat dilihat pada Gambar 12. Ketika pemain 
memilih jawaban yang salah (Gambar 13) maka timer game yang berupa lambang hati dan darah akan berkurang dan petunjuk selanjutnya tidak diberikan sehingga pemain bermain tanpa adanya petunjuk.

\section{G. Tampilan Berhenti (Pause) dan Menang}

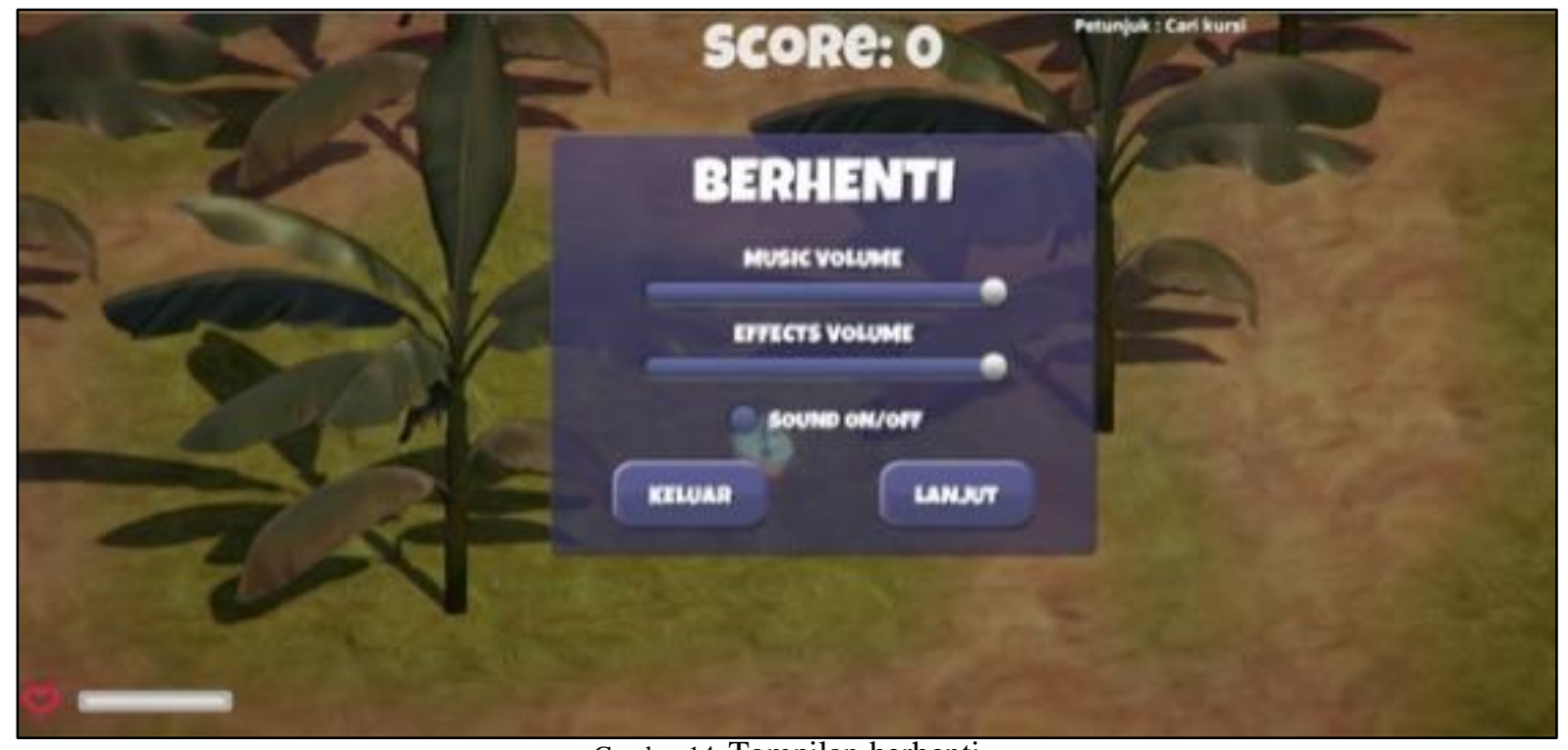

Gambar 14. Tampilan berhenti

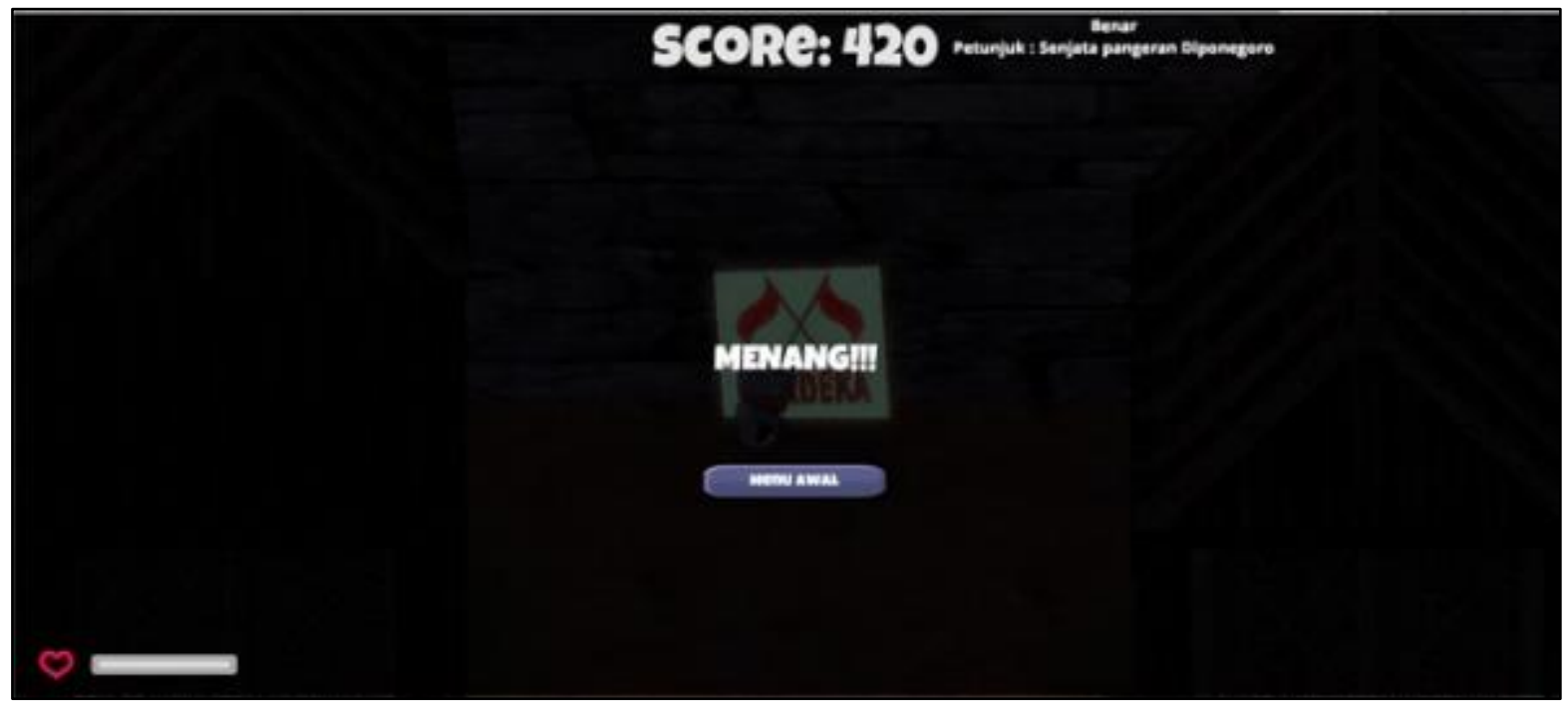

Gambar 15. Tampilan menang

Tampilan berhenti atau pause muncul ketika menekan tombol Esc seperti pada Gambar 14. Setelah itu muncul pop-up yang berisi pengaturan volume, effect volume, sound on/off, tombol keluar dan tombol lanjut. Setelah menyelesaikan misi yang sudah diberikan maka tampil scene seperti pada Gambar 15.

\section{H. Uji Program}

Uji program meliputi 5 tahapan diantaranya adalah:

a. Uji Blackbox

Pengujian blackbox dilakukan untuk menguji apakah game sudah sesuai dengan persyaratan fungsional atau belum. Dari hasil uji Blackbox, dapat diketahui bahwa semua komponen yang diuji berstatus berhasil. Adapun komponen yang diuji meliputi menu, pengaturan suara, karakter, informasi, dan soal.

b. Validasi ahli materi

Setelah perancangan dan development game telah selesai dilakukan, game yang telah diselesaikan diserahkan kepada ahli media dan ahli materi. Validasi oleh ahli media menghasilkan sebuah rekomendasi untuk membuat karakter (aktor). Validasi oleh ahli materi menghasilkan validasi yang menyatakan bahwa materi yang disajikan sudah sesuai dengan materi yang ada pada buku.

c. Revisi media

Game yang sudah dinilai dan divalidasi oleh para ahli ternyata memiliki banyak kekurangan sehingga perlu direvisi, adapun revisi yang dilakukan dapat dilihat pada Tabel 1. 
TABEL I

REVISI AHLI MEDIA

\begin{tabular}{|c|c|}
\hline Sebelum & Sesudah \\
\hline $\begin{array}{ll}\text { - } & \text { Tidak membuat karakter tapi } \\
\text { menggunakan first person } \\
\text { - } \quad \text { Tulisan menggunakan Bahasa } \\
\text { Inggris } \\
\text { - } \quad \text { Objek yang dicari tidak sesuai } \\
\text { dengan tema } \\
\text { - } & \text { Tidak menampilkan materi }\end{array}$ & $\begin{array}{l}\text { - Membuat karakter anak kecil sehingga lebih } \\
\text { menarik } \\
\text { - } \quad \text { Tulisan menggunakan Bahasa Indonesia } \\
\text { - } \text { Objek yang dicari sesuai dengan tema Game } \\
\text { - }\end{array}$ \\
\hline
\end{tabular}

d. Pengujian beta

Pengujian beta merupakan validasi dengan meminta pihak lain mencoba game yang telah dibuat. Pengujian ini bertujuan untuk memastikan apakah game yang dibuat dapat berfungsi sesuai dengan tujuannya. Pada penalitian ini pengujian beta dilakukan dengan menggali data menggunakan media kuesioner yang terdiri dari 8 pertanyaan dan disebarkan pada 24 responden. Yang mana responden merupakan siswa-siswi dari kelas VIII MTs Al-Anwar, hal ini dikarenakan materi sejarah kemerdekaan Indonesia diberikan pada siswa-siswi kelas VIII. Adapun daftar pertanyaan adalah sebagai berikut:

1. Konsep permainan game ini menarik.

2. Dengan adanya game ini anda menjadi lebih tertarik untuk mempelajari sejarah kemerdekaan Indonesia.

3. Tampilan game menarik

4. Dengan adanya game ini, pengetahuan anda tentang sejarah kemerdekaan Indonesia akan bertambah.

5. Materi yang diberikan sesuai dengan materi yang disampaikan di sekolah.

6. Petunjuk pada game mudah difahami

7. Misi pada game mudah diselesaikan.

8. Soal-soal yang ada pada game mudah dipecahkan

e. Analisis hasil

TABEL II

REKAPITULASI HASIL KUESIONER

\begin{tabular}{cccccc}
\hline Pertanyaan & SS & S & KS & TS & Jumlah \\
\hline 1 & 10 & 14 & & & 24 \\
2 & 9 & 13 & 2 & 24 \\
3 & 8 & 9 & 7 & & 24 \\
4 & 12 & 11 & 1 & & 24 \\
5 & 13 & 9 & 2 & & 24 \\
6 & 14 & 7 & 3 & & 24 \\
7 & 7 & 13 & 4 & & 24 \\
8 & 6 & 13 & 3 & 2 & 24 \\
\hline
\end{tabular}

TABEL III

ReKaPITUlasi KUESIONER ASPEK KeTERTARIKAN

\begin{tabular}{|c|c|c|c|c|c|}
\hline \multirow[t]{2}{*}{ Pertanyaan } & \multicolumn{4}{|c|}{ Jawaban (Skala) } & \multirow[t]{2}{*}{ Skor } \\
\hline & $\begin{array}{l}\text { SS } \\
(4)\end{array}$ & $\begin{array}{l}\text { S } \\
(3)\end{array}$ & $\begin{array}{l}\text { KS } \\
(2)\end{array}$ & $\begin{array}{l}\text { TS } \\
(1)\end{array}$ & \\
\hline Apakah (konsep permainan) game ini menarik? & 40 & 42 & 0 & 0 & 3.42 \\
\hline $\begin{array}{l}\text { Apakah anda lebih tertarik untuk mempelajari sejarah ke- } \\
\text { merdekaan Indonesia? }\end{array}$ & 36 & 39 & 4 & 0 & 3.12 \\
\hline Apakah tampilan game menarik? & 32 & 27 & 14 & 0 & 3.04 \\
\hline Rata-rata & & & & & 3.19 \\
\hline
\end{tabular}

Dari kuesioner yang telah disebar dan rekapitulasi hasil kuesioner (Tabel 2) yang dilakukan kemudian dicari nilai rata-rata. Nilai rata-rata yang diperoleh meliputi aspek ketertarikan, kemanfaatan, kesesuaian kurikulum dan kemudahan. Untuk aspek ketertarikan diambil dari rata-rata hasil kuisioner pertanyaan nomor 1, 2 dan 3 (Tabel 3). Aspek kemanfaatan diperoleh dari hasil kuisioner nomor 4 (Tabel 4) dan kesesuaian kurikulum berasal dari hasil kuisioner pertanyaan nomor 5 (Tabel 5) sedangkan hasil kuisioner dari pertanyaan nomor 6, 7 dan 8 ditarik rata-rata kemudian dijadikan sebagai nilai aspek kemudahan (Tabel 6). 
TABEL IV

REKAP KUESIONER ASPEK KEMANFAATAN

\begin{tabular}{|c|c|c|c|c|c|}
\hline \multirow[t]{2}{*}{ Pertanyaan } & \multicolumn{4}{|c|}{ Jawaban (Skala) } & \multirow[t]{2}{*}{ Skor } \\
\hline & $\begin{array}{l}\text { SS } \\
(4)\end{array}$ & $\begin{array}{l}\mathrm{S} \\
(3)\end{array}$ & $\begin{array}{l}\text { KS } \\
(2)\end{array}$ & $\begin{array}{l}\text { TS } \\
(1)\end{array}$ & \\
\hline Apakah pengetahuan anda mengenai sejarah bertambah? & 48 & 33 & 2 & 0 & 3.46 \\
\hline \multicolumn{6}{|c|}{$\begin{array}{c}\text { TABEL V } \\
\text { REKAP KUESIONER ASPEK KESESUAIAN KURIKULUM }\end{array}$} \\
\hline \multirow[t]{2}{*}{ Pertanyaan } & \multicolumn{4}{|c|}{ Jawaban (Skala) } & Skor \\
\hline & $\begin{array}{l}\text { SS } \\
(4)\end{array}$ & $\begin{array}{l}S \\
(3)\end{array}$ & $\begin{array}{l}\text { KS } \\
(2)\end{array}$ & $\begin{array}{l}\text { TS } \\
(1)\end{array}$ & \\
\hline $\begin{array}{l}\text { Apakah materi yang ada pada game sudah sesuai } \\
\text { dengan materi yang yang disampaikan disekolah? }\end{array}$ & 52 & 27 & 4 & 0 & 3.46 \\
\hline
\end{tabular}

TABEL VI

REKAPITULASI ASPEK KEMUDAHAN

\begin{tabular}{|c|c|c|c|c|c|}
\hline \multirow[t]{2}{*}{ Pertanyaan } & \multicolumn{4}{|c|}{ Jawaban (Skala) } & \multirow[t]{2}{*}{ Skor } \\
\hline & $\begin{array}{l}\text { SS } \\
(4)\end{array}$ & $\begin{array}{l}\text { S } \\
(3)\end{array}$ & $\begin{array}{l}\mathrm{KS} \\
(2)\end{array}$ & $\begin{array}{l}\text { TS } \\
(1)\end{array}$ & \\
\hline Apakah petunjuk pada game dapat difahami? & 56 & 21 & 6 & 0 & 3.46 \\
\hline $\begin{array}{l}\text { Apakah anda mengalami kesulitan dalam me- } \\
\text { nyelesaikan misi yang ada pada game? }\end{array}$ & 28 & 39 & 8 & 0 & 3.12 \\
\hline $\begin{array}{l}\text { Apakah anda kesulitan dalam menjawab soal-soal ujian } \\
\text { yang ada pada game? }\end{array}$ & 24 & 39 & 6 & 2 & 2.96 \\
\hline Rata-rata & & & & & 3.18 \\
\hline
\end{tabular}

Dari pengujian beta melalui kuesioner dapat diketahui hasil penilaian game yang meliputi aspek ketertarikan, kemanfaatan, keseuaian kurikulum, dan kemudahan yaitu:

1. Pertama, dari aspek ketertarikan mendapat skor rata-rata sebesar 3,19.

2. Kedua dari aspek kemanfaatan skor yang diperoleh sebesar 3,46.

3. Ketiga, dari hasil kuesioner aspek kesesuaian kurikulum memiliki skor nilai 3,46.

4. Aspek yang terakhir yaitu aspek kemudahan, yang mana dari hasil kuesioner mempunyai skor nilai 3,18 .

\section{KESIMPULAN}

Dari penelitian yang dilakukan, kesimpulan yang didapat adalah sebagai berikut:

1. Game dolanan sejarah dapat meningkatkan minat belajar yang mana bisa dinilai dari tingginya hasil pengujian beta pada jawaban sangat setuju, yaitu mencapai 46,25\% dan lebih tinggi dibandingkan jawaban setuju, kurang setuju dan tidak setuju. Untuk jawaban setuju, hasil rekapitulasi jawaban mencapai $43,25 \%$, jawaban kurang setuju $9,75 \%$, dan sisanya sebesar $0,75 \%$ adalah jawaban tidak setuju. Adapun aspek yang digunakan pada penilaian game tersebut meliputi aspek ketertarikan, kemanfaatan, kesesuaian kurikulum, dan aspek kemudahan.

2. Hasil penilaian terhadap game dolanan sejarah memberikan hasil yang baik (skala maksimum 4) dari aspek ketertarikan dengan skor 3,19, aspek kemanfaatan dengan skor 3,46, aspek kesesuaian kurikulum memiliki skor sebesar 3,46, dan aspek kemudahan dengan skor 3,18.

\section{Daftar Pustaka}

[1] Y. R. Subakti, "Paradigma Pembelajaran Sejarah Berbasis Konstruktivisme," Jurnal SPPS, vol. 24, no. 1, pp. 31-53, 2010.

[2] J. Sayono, "Pembelajaran Sejarah di Sekolah: Dari Pragmatis ke Idealis," Jurnal Sejarah dan Budaya, vol. 7, no. 1, pp. 9-17, 2013.

[3] R. E. Ferdig, Learning Process and Violent Video Games. Hand Book of Research on Effective Electronic Game in Education, vol. 2, Florida: University of Florida, 2009.

[4] S. Sugar and K. K. Sugar, Primary Games: Experiential Learning Activities for Teaching Children K-8, San Francisco: John Wiley \& Sons, 2002.

[5] D. Arsenault, "Video Game Genre, Evolution and Innovation," Eludamos. Journal for Computer Game Culture, vol. 3, no. 2, pp. 149-176, 2009. 
Bachtiar dan Hakim — Game petualangan untuk meningkatkan minat ...

pISSN: 2087-8893

eISSN: $2527-3671$

[6] B. Cavallari, J. Heldberg and B. Harper, "Adventure Games In Education: A Review," Australian Journal of Educational Technology, vol. 8, no. 2, pp. 172-184, 1992. 